\title{
"PREPARE-SE DESDE JÁ": OS IMPRESSOS DE CUNHO CIVILIZATÓRIO E AS PRESCRIÇÕES PARA O COMPORTAMENTO FEMININO (ANOS 1950)
}

\author{
Luciane Sgarbi S. Grazziotin ${ }^{1}$ \\ https://orcid.org/0000-0001-5648-3855 \\ Eduardo Cristiano Hass da Silva² \\ https://orcid.org/0000-0002-3906-5448 \\ Tainá Martins de Barros 3 \\ https://orcid.org/0000-0002-8353-8361
}

RESUMO: É na esteira das pesquisas que se ocupam em compreender a sociabilidade, a civilidade e as formas de agir no ambiente privado que pesquisamos uma coleção de impressos de cunho civilizatório, denominado "Pensando em Casar". O objetivo foi atentar para as imagens relacionadas à família, no sentido de compreender as representações sobre a condição feminina nesse contexto. Foram analisadas 22 revistas publicadas originalmente da França (1954) e traduzidas quase que simultaneamente no Brasil (1955). Na análise dos documentos, destacamos duas categorias: "Representações de casamento e família" e "Comportamento feminino: entre a espera e a conquista". Nesse conjunto, as representações sobre o comportamento feminino evidenciam que as mulheres a quem se destinava a revista eram favorecidas economicamente. As imagens indicam que as leitoras deveriam estar sempre preparadas para conquistar um marido, formar uma família e permanecer no matrimônio.

PALAVRAS-CHAVE: impressos de civilidade, cultura visual, representações femininas.

\section{"GET READY RIGHT NOW": CIVILIZATORY PRINTED MEDIA AND THE PRESCRIPTIONS FOR THE FEMININE BEHAVIOR (DECADE OF 1950)}

ABSTRACT: It is in the context of research works that seek to understand the sociability,

\footnotetext{
${ }^{1}$ Doutora em Educação (PUCRS). Professora pesquisadora da Universidade do Vale do Rio dos Sinos (UNISINOS). São Leopoldo, RS, Brasil. Isgarbi@unisinos.br

${ }^{2}$ Doutorando em Educação com bolsa CNPq na Universidade do Vale do Rio dos Sinos (UNISINOS). São Leopoldo, RS, Brasil. eduardohass.he@gmail.com

${ }^{3}$ Graduanda em Ciências Sociais na Universidade do Vale do Rio dos Sinos (UNISINOS). São Leopoldo, RS, Brasil. ttaimartins@hotmail.com
} 
the civility, and the forms of acting in private environments that we analyze a printed civilizatory collection called "Pensando em Casar" ("Thinking about Marrying"). The aim was to observe the family images, in order to understand the representations of the feminine condition in this context. 22 magazines published originally in France (1954) and translated almost simultaneously in Brazil (1955) were analyzed. In the analysis of the documents, we highlight two categories: "Representations of marriage and family", and "Feminine behavior: between waiting and winning". In this set, the representations on the feminine behavior show that the women who bought the magazine were economically privileged. The images show that the readers would have to be always prepared to get a husband, to form a family and to remain in the marriage.

KEYWORDS: civilizatory printed media, visual culture, feminine representations.

\section{"ESTEA PREPARADO DESDE YA": LOS IMPRESOS DE CARÁCTER CIVILIZATÓRIO Y LAS PRESCRIPCIONES PARA EL COMPORTAMIENTO FEMENINO (AÑOS 1950)}

RESUMEN: Es en el contexto de las investigaciones que buscan entender la sociabilidad, la civilidad y las formas de actuar en el ambiente privado que investigamos una colección impresos de carácter civilizatorio, llamada "Pensando em Casar". El objetivo fue atentar para las imágenes de la familia, para entender las representaciones de la condición femenina en ese contexto. Fueron analizadas 22 revistas publicadas originalmente en Francia (1954) y traducidas casi simultáneamente en Brasil. En el análisis de documentos, destacamos dos categorías: "Representaciones de unión y familia" y "Comportamiento femenino: entre la espera y la conquista". En esa sistematización, las representaciones del comportamiento femenino evidencian que las mujeres a quiénes se destinaba la revista eran favorecidas económicamente. Las imágenes indican que las lectoras deberían estar siempre preparadas para conquistar a un marido, para formar a una familia y para permanecer en el matrimonio.

PALAVRAS CLAVE: impresos de civilidad, cultura visual, representaciones femeninas.

\section{Os impressos de cunho civilizatório e a História da Educação}

Segundo Darton (1990), é possível identificar tentativas de escrita da História dos Livros ainda na Renascença e no século XIX. No entanto, é partir dos anos 1960, na França, que há uma inserção paulatina desse tema no leque de assuntos estudados pela Escola dos Annales, contexto no qual, "[...] ao invés de se deterem em detalhes da bibliografia, tentaram descobrir 
o modelo geral da produção e consumo do livro ao longo de grandes períodos de tempo" (DARTON, 1990. p. 110).

De acordo com o autor, a História dos Livros pode ser entendida como uma História Social e Cultural da Comunicação Impressa, cuja constituição se dá no cruzamento e na convergência de diversas disciplinas, como a História, a Literatura, a Sociologia e/ou a Biblioteconomia. Enxergando o objeto impresso como um todo, Darton (1990) propõe um modelo geral de análise que permite entender como os livros surgem e se difundem na sociedade. Embora possuam condições variadas e se modifiquem de um lugar para o outro, os livros passam pelo mesmo 'ciclo de vida'. Para analisar o processo de produção e circulação dos impressos, Darton (1990) propõe um circuito de comunicação composto por cinco etapas: do autor ao editor; do editor ao impressor; do impressor ao distribuidor; do distribuidor ao vendedor; do vendedor ao leitor. Segundo Darton (1990, p. 112), "o leitor encerra o circuito porque ele influencia o autor tanto antes quanto depois do ato de composição".

Em pesquisas com foco semelhante, o historiador Chartier (2004) estudou a produção e a circulação dos livros e as diferentes formas de apropriação desses artefatos nos distintos seguimentos sociais, discutindo o conceito de apropriação vinculado ao processo de interlocução entre texto e sujeito que lê. Embora discordem em determinados aspectos, ambos os autores problematizam o processo de recepção pelo leitor.

Nesta pesquisa, estudamos uma coleção de opúsculos ${ }^{4}$ de cunho civilizatório, denominada "Pensando em Casar". Não temos a intenção de analisá-la a partir de todo o seu circuito de produção e circulação, mas sim de atentar para as imagens relacionadas à família, com o objetivo de compreender as representações sobre a condição feminina em tal impresso. Desse modo, o foco recai para o último sujeito desse processo: as leitoras. Nesse âmbito, destacamos que o nosso entendimento de representação está vinculado aos "[...] esquemas intelectuais incorporados que criam as figuras graças as quais o presente pode adquirir sentido, o outro tornar-se inelegível e o espaço ser decifrado" (CHARTIER,1990, p. 17).

A revista "Pensando em Casar", aqui analisada, faz parte de um conjunto de impressos de cunho civilizatório que, no início do século XX, tiveram como objetivo o regramento da sociedade no campo da civilidade doméstica, em prol do adequado convívio coletivo. Para tanto, ocupavam-se de prescrever regras de etiqueta, cortesia e modos, além de fornecer guias para um bom comportamento no que se refere a namoro, noivado, casamento e tantas

${ }^{4}$ Opúsculo significa brochura, folheto, impresso de pequena dimensão. 
outras práticas sociais. São um tipo de literatura que circulava na sociedade brasileira à época. Segundo Rainho (1995), esse tipo de impresso de civilidade compunha um corpus agregado ao cotidiano urbano que visava à propagação de uma ordem, daquilo que precisava ser aprendido e ensinado e que era considerado civilizado. Os impressos foram, então, uma espécie de ferramenta para que se compreendessem as novas transformações sociais que avançavam na época. Tal corpus materializa-se em numerosos escritos colocados à venda ao grande público e postos em circulação em diversos estabelecimentos, incluindo instituições educativas, sobretudo em colégios católicos e em cursos para a formação de professoras.

A necessidade desse tipo de produção se relaciona a uma preocupação exacerbada em transformar o Brasil numa sociedade amplamente urbanizada, que, até o final do século XIX e o início do século XX, possuía características rurais. Para que o país absorvesse as características urbanas, esses impressos de cunho civilizatório emergiram como um instrumento para instaurar modelos de comportamento. Assim, tratava-se de um meio de implementar uma reorganização geral e criar novas reproduções das relações sociais e de conduta.

Desde a década de 1990, a literatura de cunho civilizatório, sobretudo os manuais de civilidade, tem sido foco de pesquisas acadêmicas articuladas, em grande medida, à História da Educação. Nesse sentido, destacamos os estudos de Cunha (2018, 2017, 2013, 1998); de Santos e Cunha (2017); e de Cunha e Salerno (2011). Tais trabalhos enfocam protocolos de convívio social, preceitos morais e higienistas direcionados, sobretudo, ao comportamento feminino, embora esses manuais também tivessem o objetivo de atingir a população masculina.

Segundo Cunha (2005, p. 3), “[...] os manuais de civilidade eram considerados vetores de sistemas de valores, ferramentas para a consolidação das formas e dos códigos morais e sociais". Em seu conteúdo, são incluídos diversos conselhos, orientações e regras que tinham como objetivo transmitir e prezar pelas atenções e cuidados que cada indivíduo deveria ter com o outro, em diversos espaços; tratava-se de uma nova maneira social de relacionar-se e comportar-se.

É necessário entender esses antigos paradigmas traduzidos nesses impressos para que, por meio deles, seja possível identificar as intenções da sociedade no processo de construção de determinado tipo de família ideal, atrelada a um ethos feminino, com vistas a observar como essas representações construídas ao longo de décadas ainda reverberam nos dias atuais.

Considerando a História da Educação como um campo fronteiriço 
e interdisciplinar, que toma conceitos tanto da História quanto da Educação, Stephanou e Bastos (2005) afirmam que, a partir da influência da História dos Annales, é possível observar a valorização de temas como o cotidiano, que se refere a uma história "vinda de baixo" (protagonizada por operários, mulheres e crianças). Essa outra visão de História permite um alargamento da concepção de fontes. Dessa forma, dentre as possibilidades de investigação em História da Educação, essas autoras, assim como outras pesquisadoras contemporâneas, exploram a história do livro e da leitura, dos manuais didáticos, da criança, das mulheres, dos impressos de educação e de ensino, das práticas educativas não escolares, dentre muitas outras, cada uma constituindo-se em um campo de pesquisa. Seguindo esse percurso, o estudo aqui proposto consiste em uma contribuição para a História dos Impressos, para a História das Mulheres e para a História das Práticas Educativas Não Escolares.

\section{"Pensando em Casar": a cultura visual na análise das capas}

Os exemplares do impresso "Pensando em Casar" aqui analisados faziam parte do acervo de documentos do Instituto Anchietano. Posteriormente, foram transferidos para a Universidade do Vale do Rio dos Sinos (UNISINOS) e doados ao Acervo de Documentação Escolar do Grupo de Pesquisa EBRAMIC 5 . Tais documentos consistem em impressos de cunho civilizatório publicados na metade do século XX. Os exemplares das coleções foram higienizados, organizados e salvaguardados.

De forma geral, os opúsculos são impressos em papel jornal, medindo 12 x $18 \mathrm{~cm}$; as capas trazem imagens coloridas, e o interior da revista é escrito em preto. No verso de cada número do impresso, consta a lista com o total de volumes da coleção, contabilizando 24 números $^{6}$.

Embora não seja tomado como metodologia de análise principal, o circuito de comunicação proposto por Darton (1990) oferece algumas possibilidades para o estudo desse impresso. Em relação à produção, é possível afirmar que a autoria da revista é de Gérard Petit C.S.C., e a versão original foi publicada na França, provavelmente em 19547. No Brasil, todos os números foram publicados em 1955 pela Edições Paulinas, de São Paulo, e a tradução

\footnotetext{
${ }^{5}$ EBRAMIC. Educação no Brasil: memórias, instituições e cultura escolar.

${ }^{6} \mathrm{O}$ acervo analisado contém 22 dos 24 números da coleção. A partir do verso das revistas, é possível afirmar que estão faltando os números 14 e 16, cujos títulos são, respectivamente: ‘Posso ler de tudo?' e ‘O Sacerdote, teu amigo?'.

${ }^{7} \mathrm{O}$ impresso não traz o ano exato da edição francesa. No entanto, as informações contidas na primeira página permitem afirmar que já havia uma publicação em 1954.
} 
foi feita por Lydia Christina, provavelmente no mesmo ano.

Conforme podemos observar, o impresso trata-se de uma publicação escrita por um homem, originalmente produzida na França e traduzida por uma mulher no Brasil. Esses elementos são importantes para refletirmos sobre a História da coleção "Pensando em Casar". Como destaca Darton (1990), a história dos impressos se interessa também pelas variações no tempo e no espaço, bem como pelas suas relações com os sistemas econômicos, sociais, políticos e culturais. Assim, publicadas com pouco tempo de diferença, 1954 e 1955, respectivamente, as edições francesa e brasileira estão inseridas dentro de contextos específicos.

Do autor francês até as leitoras brasileiras, o impresso passou por outros sujeitos, como editores, tradutora, impressores, distribuidores e vendedores. Mas a quem essa revista se direcionava? $\mathrm{O}$ n. 5 do impresso permite identificar quem eram as leitoras a quem se destinava:

\footnotetext{
Para vocês, jovens de quinze a vinte e cinco anos, não é fácil admitir, no correr da vida quotidiana, que a faculdade característica do homem é a razão! Como a reconheceriam no tumulto das forças contraditórias que os assaltam por todos os lados? (PETIT, 1955, p. 3 - "Teu coração... e seus segredos").
}

No excerto acima, o autor se refere às leitoras como jovens de 15 a 25 anos, para as quais "não é fácil admitir, [...] que a faculdade característica do homem é a razão!", estando implícito que essa não é a faculdade atribuída ao sexo feminino. Além disso, o trecho evidencia o caráter de diálogo do impresso, recurso que é utilizado ao longo do texto, como se autor e leitora estivessem conversando. A narrativa se estrutura a partir desse jogo constante de perguntas e respostas: "Digam-me, é verdade ou não é, que o rapaz se exalta com a própria força física, tanto quanto a jovem com seus encantos femininos?" (PETIT, 1955, p. 8 - "Teu coração... e seus segredos").

Esses apontamentos iniciais sobre o impresso têm a intenção de situar o leitor sobre o que caracteriza o veículo em questão, quanto ao público leitor e aos discursos que produz. Destacamos, no entanto, que nossa intenção é de analisar as capas do periódico, identificando as prescrições de ordem moral, centradas nos discursos sobre tempos, lugares, direitos e deveres que envolvem a educação feminina. Para isso, tomamos como gradiente de análise os Estudos Visuais.

Segundo Meneses (2003), o conhecimento histórico pode e tem se beneficiado muito dos Estudos Visuais, desde que os historiadores deslocaram 
seu interesse do campo das fontes visuais para o da visualidade como um objeto detentor de historicidade. Como visualidade, o autor entende o significativo potencial cognitivo das imagens, cabendo aos historiadores explorarem-no.

Enquanto na Antiguidade e na Idade Média havia uma relação de afetividade com as imagens, o Renascimento permitiu novos usos desses registros, bem como a exploração de sua função cognitiva e técnica. Nos séculos XIX e XX, a História da Arte permitiu ultrapassar o horizonte da visualidade, trazendo uma marca documental e classificatória para tais recursos. No século XX, a aproximação da Arte com a Antropologia possibilitou a emergência de uma Antropologia Visual, área que entende a natureza diversificada das fontes, bem como a produção, a circulação e o consumo das imagens - inclusive a interação entre observador e observado.

Nessa esteira de transformações, Meneses (2003) discute as relações entre História e Imagem. Para o autor, a partir dos anos 1960, as fontes visuais passaram a ter significativa importância na produção do conhecimento histórico, ao mesmo tempo em que ocorriam a consolidação e a ampliação da noção de documento e a emergência de novas técnicas quantitativas e qualitativas de análise. No entanto, a história ainda continua à margem dos esforços das demais ciências humanas e sociais no que se refere ao uso das imagens com a problemática da visualidade. Nos anos 1980, a convergência de diferentes disciplinas, ao atentarem para a importância das imagens, permitiu a emergência dos estudos em Cultura Visual. Mais uma vez, a História ficou à margem desse debate (MENESES, 2003).

Diante disso, ao tomar as capas da revista "Pensando em Casar" como objeto de análise, a presente investigação contribui também para o avanço na produção do conhecimento em Cultura Visual. Nesse sentido, a investigação iniciou com a digitalização das capas de todos os números do impresso. $\mathrm{Na}$ sequência, realizou-se o processo de sistematização dessas capas a partir da organização de um quadro, contendo as principais informações de cada número, como o título e uma breve descrição da imagem.

Quadro 1 - Principais informações das capas da Revista Pensando em Casar

\begin{tabular}{|c|c|l|l|}
\hline Número & Ano & \multicolumn{1}{|c|}{ Título } & \multicolumn{1}{c|}{ Descrição da Capa } \\
\hline 1 & 1955 & Meu noivo & $\begin{array}{l}\text { Casal heterossexual branco sorrindo. } \\
\text { Mulher loira. Homem de cabelos } \\
\text { castanhos, vestindo terno e gravata. }\end{array}$ \\
\hline
\end{tabular}




\begin{tabular}{|c|c|c|c|}
\hline 2 & 1955 & Quando se ama... & $\begin{array}{l}\text { Mulher escrevendo uma carta e } \\
\text { olhando a fotografia de um homem } \\
\text { em preto e branco. Mulher trajando } \\
\text { camisa rosa e colar. Homem de terno } \\
\text { e gravata. }\end{array}$ \\
\hline 3 & 1955 & $\begin{array}{l}\text { Prepare-se... desde } \\
\text { já }\end{array}$ & $\begin{array}{l}\text { Mulher sentada em um espaço } \\
\text { externo, com uma caixa contendo } \\
\text { linhas. Mulher de verde, bordando. }\end{array}$ \\
\hline 4 & 1955 & Teu corpo e teu amor & $\begin{array}{l}\text { Mulher em espaço externo, com uma } \\
\text { raquete de tênis. Veste vestido e } \\
\text { sinto. }\end{array}$ \\
\hline 5 & 1955 & $\begin{array}{l}\text { Teu coração... e seus } \\
\text { segredos }\end{array}$ & $\begin{array}{l}\text { Mulher em espaço interno, sentada e } \\
\text { levemente inclinada sobre uma mesa. } \\
\text { Mesa contendo perfumes e joias. } \\
\text { Mulher segura um bilhete. }\end{array}$ \\
\hline 6 & 1955 & $\begin{array}{l}\text { A conquista do } \\
\text { querer }\end{array}$ & Mulher subindo em um avião. \\
\hline 7 & 1955 & $\begin{array}{l}\text { Quando a } \\
\text { Consciência fala... }\end{array}$ & $\begin{array}{l}\text { Homem de pé, vestindo terno e } \\
\text { gravata oferecendo um copo de } \\
\text { bebida para a mulher. Mulher sentada } \\
\text { em um sofá, de saia, com camisa e } \\
\text { joias, negando o copo de bebida. }\end{array}$ \\
\hline 8 & 1955 & $\begin{array}{l}\text { A inteligência, luz do } \\
\text { coração }\end{array}$ & $\begin{array}{l}\text { Casal. Mulher sentada em um sofá, } \\
\text { de vestido rosa, chorando com o } \\
\text { rosto coberto por um lenço branco. } \\
\text { Homem de pé, de smoking }\end{array}$ \\
\hline 9 & 1955 & Nós dois... & $\begin{array}{l}\text { Casal escalando uma montanha. } \\
\text { Homem à frente, puxando a mulher. }\end{array}$ \\
\hline 10 & 1955 & Bastará o amor? & $\begin{array}{l}\text { Casal de barco à vela. Mulher de saia } \\
\text { e blusa. Homem de calça e camiseta. }\end{array}$ \\
\hline 11 & 1955 & $\begin{array}{l}\text { Tenho direito de } \\
\text { agradar? }\end{array}$ & Parte do rosto de uma mulher. \\
\hline 12 & 1955 & O flirt & $\begin{array}{l}\text { Casal abraçado. Homem de terno e } \\
\text { gravata. Mulher de vestido. Interior. }\end{array}$ \\
\hline
\end{tabular}




\begin{tabular}{|c|c|c|c|}
\hline 13 & 1955 & A moda & $\begin{array}{l}\text { Mulher caminhando pela rua, } \\
\text { passando em frente ao cartaz de um } \\
\text { palhaço, sendo sua roupa parecida } \\
\text { com a do cartaz. Em segundo plano, } \\
\text { homens rindo da mulher. }\end{array}$ \\
\hline 15 & 1955 & $\begin{array}{l}\text { Os namoros } \\
\text { modernos }\end{array}$ & $\begin{array}{l}\text { Mulher trabalhando em uma } \\
\text { máquina de escrever, provavelmente } \\
\text { em um escritório. Veste um terno } \\
\text { preto. Homem de pé, nas suas costas, } \\
\text { vestindo terno e gravata. }\end{array}$ \\
\hline 17 & 1955 & E a dança? & $\begin{array}{l}\text { Duas mulheres, uma adulta e uma } \\
\text { criança dançando. Vestem roupa de } \\
\text { bailarina e sapatilhas. }\end{array}$ \\
\hline 18 & 1955 & Matrimônio moderno & $\begin{array}{l}\text { Homem e mulher vestidos de noivos, } \\
\text { andando em uma corda. Padre } \\
\text { em uma escada, provavelmente } \\
\text { realizando o matrimônio do casal. }\end{array}$ \\
\hline 19 & 1955 & $\begin{array}{l}\text { Muda o Matrimônio } \\
\text { cristão? }\end{array}$ & $\begin{array}{l}\text { Casal de idosos; homem vestindo } \\
\text { terno e gravata, e mulher com joias. } \\
\text { Imagem de Jesus Cristo ao fundo. }\end{array}$ \\
\hline 20 & 1955 & $\begin{array}{l}\text { Um contrato como } \\
\text { os outros? }\end{array}$ & $\begin{array}{l}\text { Homens e mulheres árabes. A } \\
\text { imagem sugere que a mulher estaria } \\
\text { sendo comprada/vendida por um dos } \\
\text { homens. Mulher veste burca. }\end{array}$ \\
\hline 21 & 1955 & Por que casar? & $\begin{array}{l}\text { Homem e mulher embarcando em } \\
\text { um navio. Carregam mala. Homem } \\
\text { veste terno e gravata. }\end{array}$ \\
\hline 22 & 1955 & Divorciar-me? & $\begin{array}{l}\text { Casal e uma criança (menina) em um } \\
\text { ambiente interno. Casal discute, e } \\
\text { criança cobre o rosto. Homem veste } \\
\text { terno e gravata; a criança, um vestido; } \\
\text { e a mulher, blusa e joias. }\end{array}$ \\
\hline 23 & 1955 & Não é um "solo" & $\begin{array}{l}\text { Homem e mulher em ambiente } \\
\text { interno, sentados, tocam piano. }\end{array}$ \\
\hline
\end{tabular}




\begin{tabular}{|c|c|c|c|c|}
\hline 24 & 1955 & $\begin{array}{l}\text { Felicidade } \\
\text { Matrimônio }\end{array}$ & & $\begin{array}{l}\text { Homem, mulher e duas crianças } \\
\text { sentados em um ambiente interno, } \\
\text { provavelmente uma sala. Homem } \\
\text { veste terno e gravata; menino, calça } \\
\text { e camiseta. }\end{array}$ \\
\hline
\end{tabular}

Fonte: Elaborado pelos autores.

Conforme podemos observar no quadro, o conjunto contém 22 dos 24 números que compõem a coleção, todos publicados no ano de 1955 . Os títulos são incisivos quanto às condutas desejadas: por exemplo, a capa "Prepare-se... desde já" apresenta na capa uma mulher que borda, preparando seu enxoval de casamento; já o volume "Quando a Consciência fala..." traz na capa um homem de pé, vestindo terno e gravata e oferecendo um copo de bebida para a mulher, que, sentada em um sofá, nega o copo. Dessa forma, as imagens trazem representações de um ideal de comportamento da mulher que deseja constituir uma família. De forma geral, as capas sugerem a não se desviar do caminho moral, ser sensível, tímida e reverente; não ser vulgar; seguir regras para o amor e para o matrimônio; e ter o máximo de cuidado com a paixão. Assim, toda a personificação de um determinado ethos feminino é observada ao longo das publicações.

\section{"Pensando em Casar": normas e condutas nas imagens das capas}

Após esses apontamentos iniciais, reiteramos que as representações de casamento, família e comportamento feminino são a tônica das imagens observadas. Passemos assim à análise das capas que reforçam esses estereótipos.

De forma geral, alguns elementos são constantes, como por exemplo o nome da revista, "Pensando em Casar", que aparece sempre na parte superior esquerda do impresso, em diagonal, bem como o número da revista. Já o nome do autor aparece na parte inferior, na diagonal direita. $\mathrm{O}$ centro geométrico e visual das capas traz uma imagem, sempre relacionada ao tema da edição. Em todos os números, observa-se a presença de uma ou mais mulheres, e as cores de fundo variam entre amarelo, azul, rosa e verde. A capa do primeiro número permite identificar alguns desses elementos: 


\section{Figura 1 - Capa da Revista "Pensando em Casar", no 1 - "Meu Noivo"}

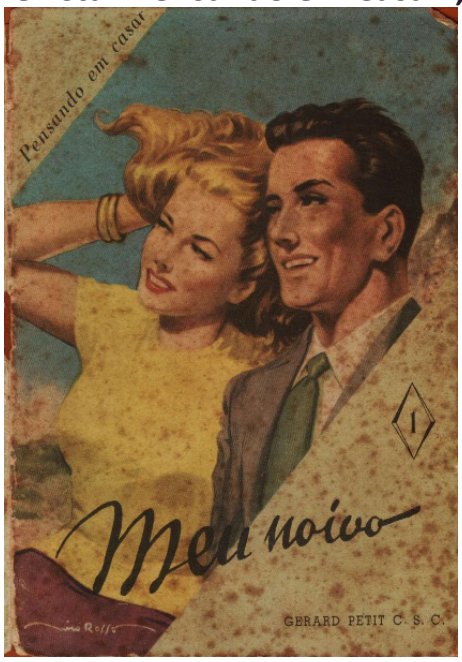

Fonte: "Pensando em Casar", no 1, 1955.

A capa do $\mathrm{n}$ - 1 da revista traz, como anteriormente citado, o título do número, o nome do autor, o número da publicação e, no centro visual e geométrico, uma imagem. Nesse caso, podemos observar um casal heterossexual branco sorrindo. Enquanto a mulher é loira, aparece vestindo blusa amarela e usando joias, o homem aparece de cabelos castanhos, vestindo terno e gravata. Ambos aparecem sorrindo, com corpos e o rosto levemente em diagonal.

Segundo Cunha (1999), ao olhar para a materialidade das capas, dos títulos, das disposições tipográficas, dos discursos e da suavidade da linguagem, conseguimos analisar as estratégias e os dispositivos que contribuíram para uma educação cotidiana feminina de sensibilidade, romantismo, pureza e polidez frente às figuras masculinas e à sociedade, bem como o favorecimento desse imaginário de encantamento. Nesse contexto, a leitura é entendida como uma prática cultural, ou seja, é absorvida pela sociedade, formando um complexo de crenças, moralidade e costumes, manifestando-se como parte da cultura vigente. Conforme a autora, "[...] existe uma linguagem das imagens, que tanto podem decifrar um conjunto de signos, como um suporte para representações ideológicas" (CUNHA, 1999, p. 102).

A leitura, a observação e a sistematização das capas das revistas permitiram a emergência de duas categorias de análise: "Comportamento feminino: entre a espera e a conquista" e "Representações de casamento e família". Certamente outras categorias poderiam ser construídas; no entanto, a partir 
do referencial teórico-metodológico empregado e das escolhas feitas ao longo desta investigação, consideramos tal sistematização potente para o estudo.

\title{
Representações de casamento e família
}

Muitos anos antes da criação desses impressos, a civilidade do espírito já tinha a tutela da Igreja. Por isso, ficou a seu encargo disseminá-la. Mais especificamente, para se construir um modelo cívico de prestígio na sociedade, a primeira esfera a receber influência da Igreja e do Estado foram os hábitos rotineiros. A forma como as pessoas se comportavam, o que elas pensavam, o que elas consumiam etc. - enfim, todo um conjunto de convenções sociais recebiam intervenção dessas instituições para introduzir os signos conforme o que se esperava dos indivíduos que compunham a sociedade. Segundo Rocha (2018), muitos manuais de etiqueta poderiam ser encontrados nas livrarias brasileiras, pois se acreditava que contribuíam para ordenar os modos de se comportar, vestir, agir e falar. A ordenação desses modos era vista como imprescindível para polir os costumes e o requinte nas formas de apresentação à sociedade, que se tornaria, então, civilizada.

Revel (1991, p. 166), ao definir civilidade, afirma que "[...] civilidade é, acima de tudo, uma arte sempre controlada, da representação de si mesmo para os outros, um modo estritamente regulamentado de se mostrar a identidade que se deseja ver reconhecida". Segundo Chartier (2002, p. 17):

\begin{abstract}
As representações do mundo social [...], embora aspirem à universalidade de um diagnóstico fundado na razão, são sempre determinadas pelos interesses de grupo que as forjam. Daí, para cada caso, o necessário relacionamento dos discursos proferidos com a posição de quem os utiliza. [...] As percepções do social não são de forma alguma discursos neutros: produzem estratégias e práticas (sociais, escolares, políticas) que tendem a impor uma autoridade à custa de outros, por elas menosprezados, a legitimar um projeto reformador ou a justificar, para os próprios indivíduos, as suas escolhas e condutas.
\end{abstract}

Com essa afirmação, o autor traz a ideia da representação como uma ferramenta de internalização simbólica que emerge a partir de práticas socialmente desejáveis e culturalmente construídas em determinados grupos - que, nesse caso, eram orientados pela Igreja. Independentemente das vontades individuais, esse processo construiu ações que influenciaram suas condutas. Ou seja, as representações dos impressos afetavam diretamente os comportamentos e eram internalizadas por suas leitoras. 
Para Darton (1990), os leitores são elementos fundamentais do circuito de comunicação dos impressos, encerrando o circuito e, ao mesmo tempo, influenciando o escritor. De acordo com o autor, a própria leitura modificou-se ao longo dos séculos, podendo ser feita em voz alta e para grupos, ou em silêncio, em segredo. Desta forma, os textos moldam a recepção dos leitores, não se limitando a relatar histórias, mas também produzindo-as.

Cunha $(2005$, p. 350) reforça que "[...] os manuais de civilidade apresentavam conselhos e regras que investiam na tentativa de gerar ponderações e comportamentos que deveriam ser seguidos, tanto nas esferas públicas quanto privadas". Seus ideais, segundo a autora, eram internalizados por meio de práticas discursivas voltadas a uma contenção social sobre o comportamento das ideias e do corpo. Dessa forma, podemos questionar: quais as representações de casamento e família presentes nas capas da revista "Pensando em Casar"? Na sequência, apresentamos as capas que compõem essa categoria:

Figura 2 - Capas da Revista "Pensando em Casar": categoria de análise "Representações de casamento e família"

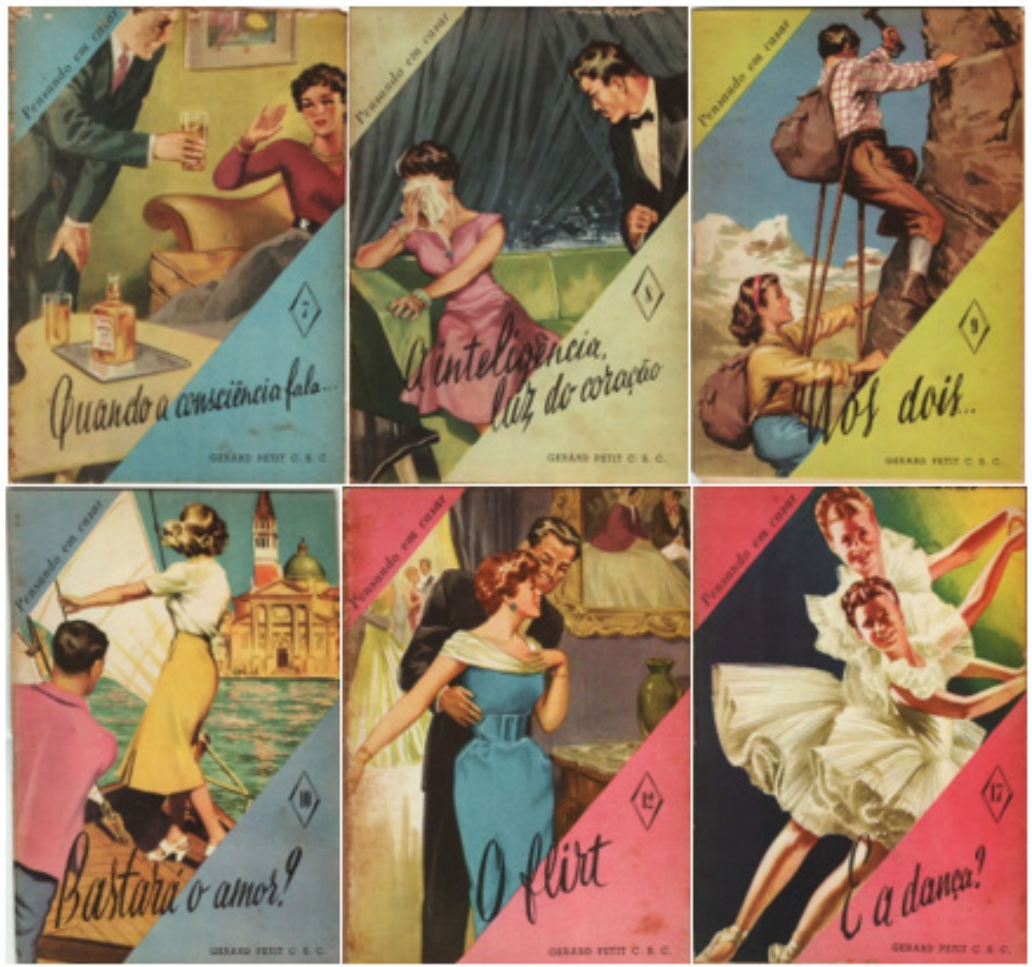

Rev. Fac. Educ. (Univ. do Estado de Mato Grosso), Vol. 33, Ano 18, № 1, p. 227-246, jan./jul., 2020. 


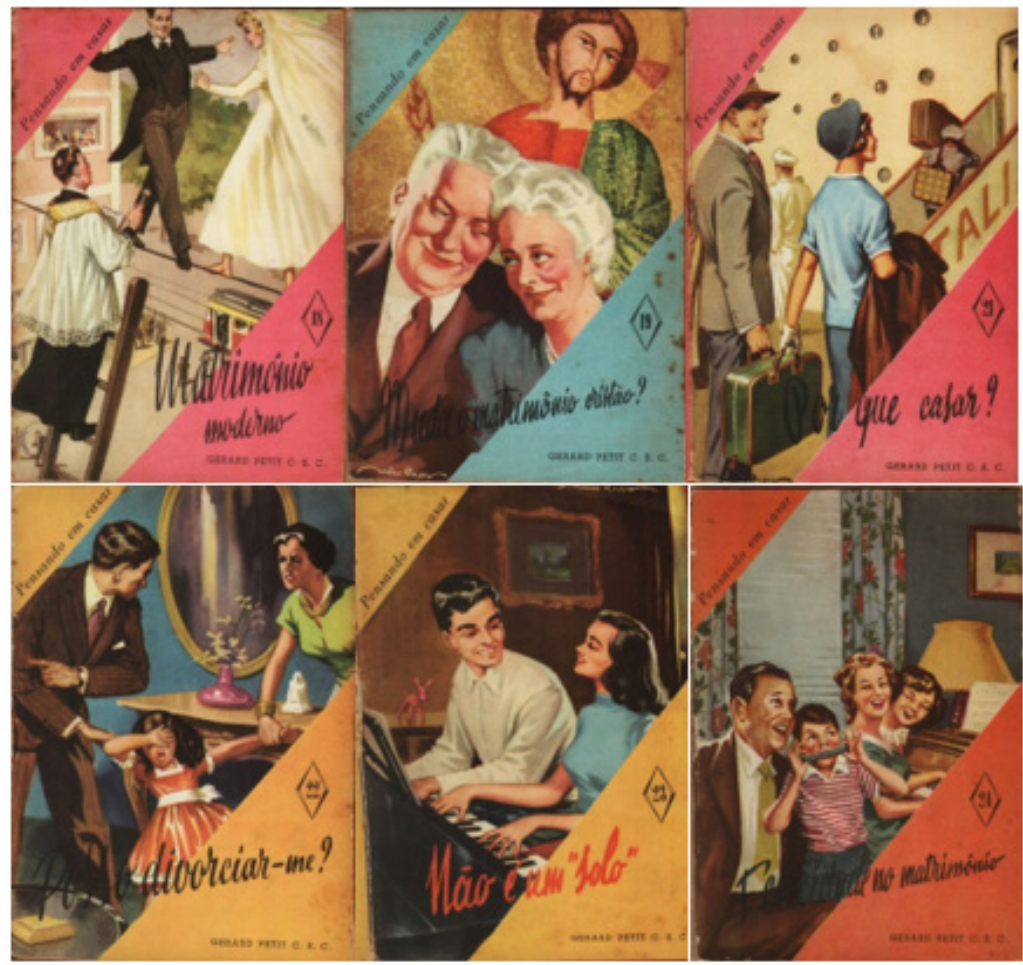

Fonte: "Pensando em Casar", n.os 7, 8, 9, 10, 12, 17, 18, 19, 21, 22, 23 e 24 (1955).

Conforme podemos observar, a categoria "Representações de casamento e família" é composta por um total de doze capas. O centro visual de todas elas traz alguma imagem relacionada ao título da edição. Além disso, destacamos que todas as capas contam com uma mulher, excetuando-se a de número 17.

As imagens instigam a pensar em cumplicidade, companheirismo, parceria; e são legitimadas por textos como "Não é um solo", "Nós dois...", "Felicidade no Matrimônio" e "Muda o Matrimônio cristão?".

As capas 7 e 8 trazem pequenas situações de atritos, e a mensagem tem cunho moralizante. A primeira conta com um homem de pé, vestindo terno e gravata, e uma mulher sentada em um sofá, de saia, camisa e joias. 0 homem parece oferecer um copo de bebida para a mulher, que, por sua vez, nega-o. O título desse número é "Quando a consciência fala...", sugerindo que a mulher deve ouvir sua consciência, evitando beber. A capa 8 também apresenta um casal; a mulher encontra-se sentada em um sofá, usando vestido 
rosa. O homem encontra-se de pé, de smoking. A mulher chora com o rosto coberto por um lenço.

Ambas as imagens apresentam locais internos, que podem ser entendidos como a sala de uma casa. Esse local refere-se à esfera da vida privada do casal, para a qual a revista se volta. Além disso, nos dois casos, é possível observar que as mulheres encontram-se sentadas, enquanto os homens são representados em pé, oferecendo algo ou dirigindo-se à mulher. É importante salientar ainda a postura das mulheres, que, em ambos os casos, são representadas de forma levemente deitada, inclinada.

O espaço interno é também representado na edição 12, "O Flirt", que traz um casal abraçado; o homem veste terno e gravata, enquanto a mulher está de vestido. $O$ traje do casal e o fundo da imagem sugerem que eles se encontram em uma festa. O homem segura a mulher pela cintura, bem marcada pelo vestido. Esse ambiente interno, da vida privada do casal, aparece também da edição número 23 , "Não é um solo". O número apresenta um casal sentado frente a um piano, sugerindo que ambos tocam juntos, são sendo apenas 'um solo'.

As vestimentas são uma chave de análise. As mulheres estão sempre de vestido (exceto quando estão praticando esportes, como no caso do alpinismo), que é símbolo de feminilidade. Enquanto isso, os homens aparecem de terno, símbolo de distinção (excetuando-se, igualmente, os momentos em que aparecem praticando esportes).

Os quatro números até aqui analisados permitem identificar a representação de papéis e lugares sociais bem demarcados, tanto para o homem quanto para a mulher. Conforme salienta Cunha (2005), considerando os pressupostos de civilidade em voga, é de se imaginar que a representação da mulher e o seu papel também sofressem grandes consequências através desses parâmetros idealizados e instituídos no processo de civilizar. O controle dos desejos pessoais, as formas de tratamento de determinados cidadãos, as diferenças entre o feminino e o masculino, entre outros, constituíram-se a partir das primeiras décadas do século XX, e estão inscritos nos discursos de civilidade indicados nas capas.

Enquanto as capas anteriores retratavam cenas de interior, seja da casa ou de alguma festa, as capas dos números 9, 10 e 21 apresentam cenas no exterior. O número 9, "Nós dois...", retrata um casal escalando uma montanha; o homem vai à frente, desbravando o caminho, ao mesmo tempo em que leva a mulher, que, por sua vez, encontra-se atrás do marido, seguindo seus passos. A capa 10 apresenta um casal de barco à vela, com a mulher vestindo 
blusa, saia e sapatos de salto, enquanto o homem veste calça e camiseta. $\mathrm{Na}$ sequência, o número 21, "Por que casar?", apresenta um casal embarcando em um navio, rumo a uma viagem. Nesses casos, o companheirismo é a tônica, sem nunca deixar de colocar a mulher em segundo plano, com toda a feminilidade que lhe é peculiar.

Especificamente voltadas para o ritual do matrimônio estão as capas dos números 18 e 19. O primeiro, cujo título é "Matrimônio moderno", apresenta um casal; ambos estão vestidos de noivos, andando em uma corda bamba, ao mesmo tempo em que se observa um padre em uma escada, provavelmente tentando realizar o casamento. A capa parece alertar para os perigos do matrimônio moderno, considerando o cenário com a corda bamba. Já a edição 19, "Muda o matrimônio cristão?", apresenta um casal abraçado. É importante destacar que esse é o único número que conta com um casal de idosos. Eles trocam olhares; e, ao fundo, observa-se a imagem de Jesus Cristo, provavelmente para construir a ideia de sacralização do matrimônio, que seria indissolúvel.

Algumas representações de família são mais visíveis nos números 17,22 e 24 . A primeira conta com duas mulheres na capa, uma adulta e uma criança, ambas vestindo roupas de bailarina e sapatilhas. A imagem sugere que sejam mãe e filha dançando juntas. Por sua vez, o número 22 apresenta um casal e uma criança (menina). A disposição dos corpos, o rosto e os gestos do casal sugerem que estão discutindo, ao mesmo tempo em que a criança, com o rosto coberto, parece chorar. A capa refere-se ao título "Divorciar-me?", parecendo colocar-se contra essa possibilidade. Para finalizar, a capa "Felicidade no matrimônio" refere-se ao número 24, que apresenta um homem e uma mulher, provavelmente esposo e esposa, acompanhados de duas crianças. Todos parecem sorrir ao som de um piano, tocado pela mulher-mãe e pela menina-filha, e de uma gaita de boca, tocada pelo menino-filho. $\mathrm{O}$ cenário enfatiza, portanto, uma família unida e alegre - e o protagonismo ao alegrar o lar é feminino.

\section{Comportamento feminino: entre a espera e a conquista}

Passemos agora à análise das capas que compõem a categoria "Comportamento feminino: entre a espera e a conquista", que totalizam nove números, conforme se observa na sequência: 
Figura 3 - Capas da Revista "Pensando em Casar": categoria de análise "Comportamento feminino: entre a espera e a conquista"

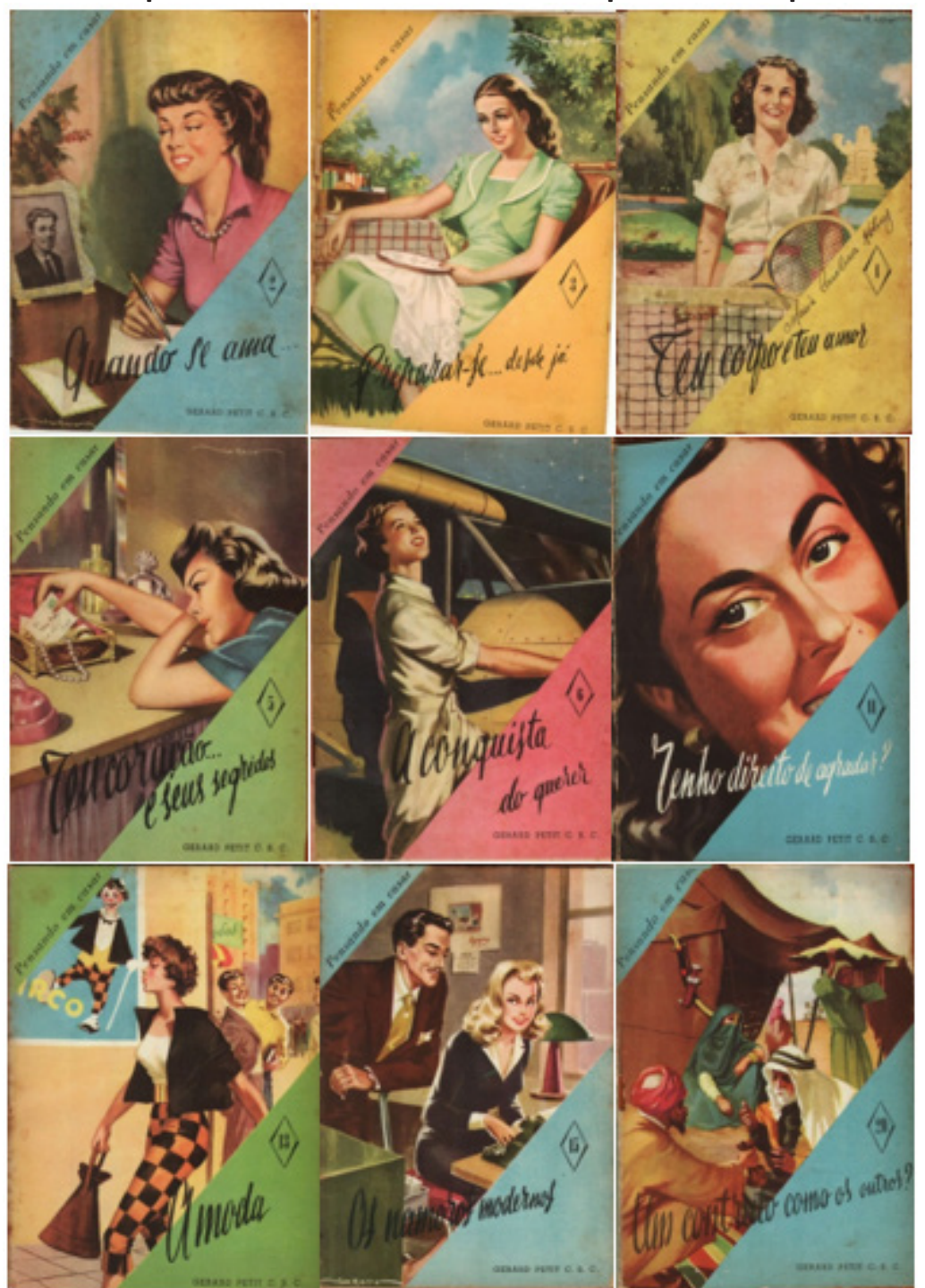

Fonte: "Pensando em Casar", n. ${ }^{\text {s }}$ 2, 3, 4, 5, 6, 11, 13, 15 e 20 (1955)

Nas capas analisadas nesta seção, a ênfase não é a família, e sim as mulheres, que, de modo geral, aparecem desacompanhadas. As imagens 
femininas são representadas em atitude sonhadora e contemplativa, ou em trabalho doméstico, conforme as capas 2, 3, 5 e 11. Em outras capas, embora as mulheres ainda estejam sozinhas, infere-se que estão em companhia masculina, conforme as imagens 4 e 6 . Ainda há aquelas que estão, de fato, em companhia masculina - vide imagens 15 e 20.

A imagem 13 explicita uma crítica à mulher representada, que tem uma atitude que remete a irreverência e autoconfiança. Ela se encontra sozinha; a cabeça está levemente erguida, em uma representação de autossuficiência. Nessa imagem, há uma clara ridicularização ao seu estilo moderno de vestir: sua roupa se assemelha à imagem de um palhaço que aparece na mesma capa.

Embora seja uma aparente exceção, a imagem representada se enquadra nessa categoria, pois entendemos que ela está vestida de forma "irreverente" para a conquista. Em contrapartida aos rostos sorridentes das outras mulheres, essa é a única que está séria, mas cuja atitude é, explicitamente, condenada e considerada equivocada.

\section{Considerações finais}

De modo geral, em todas as capas da Revista "Pensando em Casar", o ambiente doméstico predomina. Nos casos em que se encontra fora dele, a mulher está acompanhada; quando não está, a imagem sugere crítica. Além disso, o olhar da mulher e sua postura sugerem submissão, subalternidade, em atitudes que indicam espera. Ao encontro disso, em uma análise da construção social do papel feminino, Perrot $(2005$, p. 10) diz que "[...] sua postura normal é a escuta, a espera, o guardar as apalavras no fundo de si mesmas. Aceitar, conformar-se, obedecer, submeter-se e calar-se, esse silêncio [...] não é só da fala, mas da expressão, gestual ou escriturária".

Quanto à estética dessas mulheres, as roupas são elegantes. O piano é um instrumento que se evidencia em alguns volumes, bem como o acesso a aviões e barcos. Além disso, o tênis e o alpinismo são esportes que se destacam. Nesse conjunto de representações, é evidente o indicativo de que as mulheres a quem se dirige o opúsculo são favorecidas economicamente. De modo geral, os comportamentos desejados têm como foco as mulheres de lares estruturados, cristãos, elegantes e clássicos. Considerando tais aspectos, parafraseando Cunha (1999), as capas nos instigam a inferir que as mulheres bem casadas seriam "nobres, ricas e felizes". 


\section{Referências}

CHARTIER, R. A História Cultural: entre práticas e representações. Rio de Janeiro: Ed. Difel, 2002.

CHARTIER, R. Leituras e Leitores na França do Antigo Regime. São Paulo: UNESP, 2004.

CUNHA, M. T. S. Tenha modos! de civilidade e etiqueta na escola normal (anos 1920-1960). Florianópolis: UDESC, 2005.

CUNHA, M. T. S. Armadilhas da Sedução: os romances de M. Delly. Belo Horizonte: Editora Autêntica, 1999.

CUNHA, M. T. S. Espantar Vícios?: Prescrições para a Saúde Física e Moral em Manuais de Civilidade (Santa Catarina/Brasil - Década de 1950). Sisyphus Journal of Education, Lisboa, v. 6, n. 2, p. 82-100, maio/ago. 2018.

CUNHA, M. T.; SANTOS, M. R. Preceitos para bem viver: um estudo sobre manuais de civilidade e etiqueta na década de 1950. Revista Comunicações, São Paulo, v. 24, n. 3, p. 191-211, set./dez. 2017.

CUNHA, M. T. S. Das mãos para as mentes: protocolos de civilidade em um jornal escolar/SC (1945-1952). Educar em Revista, Curitiba, n. 49, p. 139-159, jul./set. 2013.

CUNHA, M. T. S.; SALERNO, L. P. Discursos para o feminino em páginas da revista Querida (1958-1968): aproximações. Educar em Revista, Curitiba, n. 40, p. 127-139, jun. 2011.

CUNHA, M. T. S. Os Romances e a Construção de um Imaginário Feminino nas décadas de 1940/60. Territórios e Fronteiras, Cuiabá, v. 2, n. 3, p. 95-104, 1998.

DARTON, R. O Beijo de Lamourette - Mídia, cultura e revolução. Tradução de Denise Bottman. São Paulo: Companhia das Letras, 1990.

MENESES, U. T. Bezerra de. Fontes visuais, cultura visual, História visual. Balanço provisório, propostas cautelares. Revista Brasileira de História, São Paulo, v. 23, n. 45, p. 11-36, jul. 2003.

RAINHO, M. C. T. A distinção e suas normas: leituras e leitores dos manuais de etiqueta e civilidade. Rio de Janeiro, século XIX. ACERVO: Revista do Arquivo Nacional, Rio de Janeiro, v.8., n.01/02, jan./dez. 1995. 
REVEL, J. Os usos da civilidade. In: ARIÈS, P.; CHARTIER, R. História da vida privada: da renascença ao século das luzes. São Paulo: Companhia das Letras, 1991. p.169-209. v. 3.

ROCHA, R. C. L. Manuais de civilidade e educação: "A Conduta da juventude feminina" de Sophie Christ. Tese (Doutorado em Educação). Programa de Pós-Graduação em Educação, Universidade Metodista de Piracicaba. Piracicaba: UNIMEP, 2018.

SANTOS, M. R.; CUNHA, M. T. S. Para civilizar uma nação: um estudo sobre um livro escolar de Educação Moral e Cívica em Florianópolis/1978. Atos de Pesquisa em Educação, Blumenau, v. 12, n. 2, p. 490-511, maio/ago. 2017.

STEPHANOU, M.; BASTOS, M. H. C. História, memória e História da Educação. In:

STEPHANOU, M.; BASTOS, M. H. C. (Orgs.). Histórias e Memórias da Educação no Brasil. VIII - Século XX. Petrópolis, RJ: Vozes, 2005. p. 416-429.

Data de recebimento: 04.10 .2019

Data de aceite: 08.07.2020 